Article

\title{
Construction and Application of the Evaluation System of Natural Resources Asset Accountability Audit of Officials: A Case Study of Jiangxi, China
}

\author{
Huanhuan Xiong ${ }^{1,2}, \mathrm{Yi} \mathrm{Li}^{2, *}$ and Jialin $\mathrm{He}^{2}$ \\ 1 Research Center of the Central China Economic Development, Nanchang University, \\ Nanchang 330031, China; xionghuanhuan@ncu.edu.cn \\ 2 School of Economics and Management, Nanchang University, Nanchang 330031, China; \\ hajialin@email.ncu.edu.cn \\ * Correspondence: liyi2021@email.ncu.edu.cn
}

Citation: Xiong, H.; Li, Y.; He, J. Construction and Application of the Evaluation System of Natural Resources Asset Accountability Audit of Officials: A Case Study of Jiangxi, China. Sustainability 2022, 14, 528. https://doi.org/10.3390/ su14010528

Academic Editor: Khalid Zaman

Received: 10 November 2021

Accepted: 30 December 2021

Published: 4 January 2022

Publisher's Note: MDPI stays neutral with regard to jurisdictional claims in published maps and institutional affiliations.

Copyright: (C) 2022 by the authors. Licensee MDPI, Basel, Switzerland. This article is an open access article distributed under the terms and conditions of the Creative Commons Attribution (CC BY) license (https:// creativecommons.org/licenses/by/ $4.0 /)$.

\begin{abstract}
At the Third Plenary Session of the 18th Central Committee of the Communist Party of China, the Central Committee first proposed the establishment of the Natural Resources Asset Accountability Audit of Officials, which not only marked a new stage in China's ecological construction, but also triggered many scholars' discussion on the accountability audit evaluation indicator system of natural resources assets. In this paper, the combination of entropy weight method and TOPSIS method is introduced into the natural resource asset accountability audit evaluation system for the first time, and a system based on energy subsystem, economy subsystem and environment subsystem is constructed. The system is used to evaluate the performance of leading officials of Jiangxi Province, one of the first batch of national pilot zones for ecological conservation in China, in the responsibility of natural resource asset management from 2015 to 2019. The evaluation result indicates that the overall situation of natural resource assets in Jiangxi Province shows a steady upward trend, and the overall performance should be affirmed. The practical application of this evaluation system in the national pilot zone for ecological conservation will enlighten other provinces in China to improve the leading officials' accountability audit of natural resource assets.
\end{abstract}

Keywords: leading officials' accountability audit of natural resources; evaluation indicator system; entropy method; TOPSIS method

\section{Introduction}

Since the reform and opening up, China has achieved many miracles in economic growth. In 2020, China's GDP has reached 14.72 trillion U.S. dollars, accounting for $17.4 \%$ of global GDP [1] and the annual GDP growth rate has been maintained at 2.3\% [2]. However, after more than 40 years of extensive development, China is also facing a series of problems such as serious environmental pollution and rapid degradation of species diversity. In 2020, China's fossil fuel carbon dioxide emissions accounted for 30.64\% of global emissions [3], and China has become the world's largest carbon emitter [4].

Wackernagel proposed the ecological footprint theory in 1996. It measures the sustainable development of the region by estimating the ecological space required to maintain human natural resource consumption and assimilate human generated waste and comparing it with the ecological carrying capacity of a given area $[5,6]$. Ecological footprint has become one of the most important indicators to measure sustainability [7-10] and has attracted the attention of policy makers. The theoretical research on China's ecological footprint such as Galli, pointed out that China's ecological footprint has been increasing in recent years and has exceeded the world's average biocapacity [11]. This demand growth has exceeded the regeneration and absorption capacity of natural resources and led to unsustainability, such as high carbon emissions, land degradation and deforestation [12-14]. 
According to the Global Footprint Network [15] (Figure 1), during 1961-2017, China's ecological footprint increased from 635 billion gha to 5353 billion gha (when the calculation of ecological footprint is not based on a specific location, but based on the total average productivity around the world, the area unit is defined as "global hectare" (gha) [16]). It far exceeds the ecological carrying capacity. This reflects the growing importance of studying how to achieve a balance between economic growth and sustainable development of natural resources in China [17].

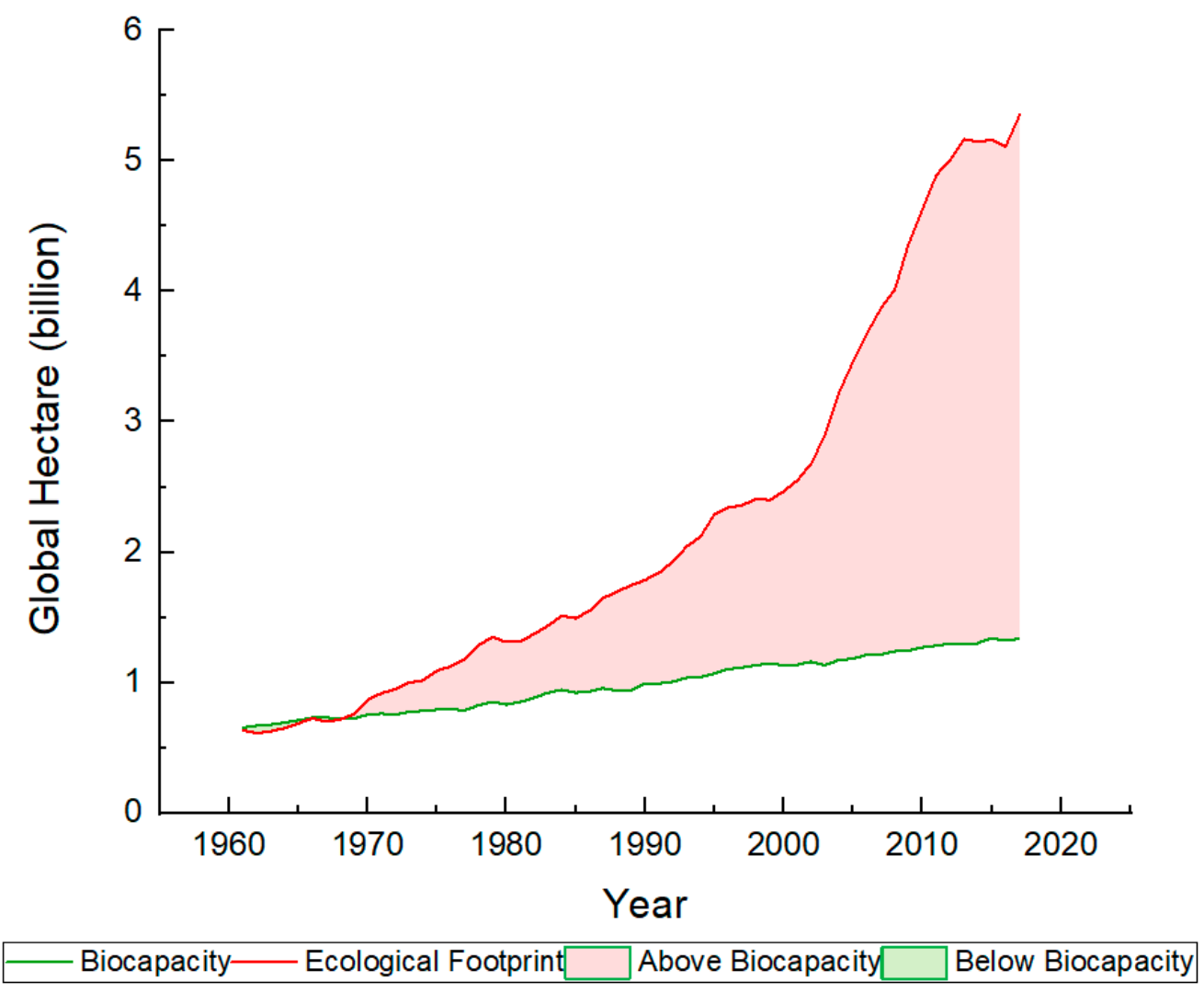

Figure 1. The Ecological Footprint and Biocapacity of China during 1961-2017. Data source: Global Footprint Network [15].

For this reason, the Chinese government has implemented a series of ecological civilization construction policies, hoping to alleviate environmental pressure from the root and change the current situation between the local GDP and environmental resource. The Third Plenary Session of the Eighteenth Central Committee of the Communist Party of China proposed the establishment of the Natural Resources Asset Accountability Audit of Officials [18] on the "Decisions of the Central Committee of the Communist Party of China on Several Major Issues of Comprehensively Deepening Reform", so that GDP is no longer the only criterion for evaluating the performance of officials. Jiangxi Province, Hunan Province, Zhejiang Province, Guizhou Province and many other provinces have successively begun to deploy the preparation of natural resource balance sheets to "record" ecological resources such as land, trees and water and "price" green water and mountains. Besides, China has made a commitment to the "3060" goal, which strives to achieve carbon peak in 2030 and carbon neutrality in 2060, reflecting the continuous transformation of China's economy towards green and sustainable development.

\subsection{Literature Review}

\subsubsection{The Benefit of Natural Resources Asset Accountability Audit of Officials}

The research on natural resources has increasingly shown a cross-departmental, crossdisciplinary trend [19]. The Natural Resources Asset Accountability Audit of Officials 
involves multiple disciplines, such as resource science and accounting [20]. It aims to quantify ecological performance assessment and accountability and urge local leading officials to comply with regulations and carry out responsibilities in resource management. This policy conforms to the future wave of China's economic development. The implementation of the Natural Resources Asset Accountability Audit of Officials will exert positive effects on the macro and micro levels. On the macro level, this system can significantly improve regional energy efficiency [21] and is conducive to promoting high-quality economic development [22]. It has a positive environmental governance effect, significantly improving the environmental governance of pilot cities [23]. On the micro level, this policy has significantly promoted the fulfillment of environmental responsibilities by enterprises [24] and will cause heavily polluting enterprises to face higher equity costs [25] and exert a positive influence in the implementation of green mergers and acquisitions by heavily polluting enterprises [26]; In addition, the Natural Resources Asset Accountability Audit of Officials also has a supervisory effect on corporate tax avoidance [27].

\subsubsection{Selection of Evaluation Indicators}

For the construction of the environmental audit evaluation system, related theoretical systems developed earlier are relatively complete [28-30]. The World Bank proposed the "Sustainable Development Indicator System" [31], which includes four levels of multidimensional indicators. The "System of Integrated Environmental and Economic Accounting (SEEA) 1993, 2003, 2012" [32-34] issued by the United Nations Statistics Division laid the basic framework of green accounting. The Global Reporting Initiative (GRI) has released the Sustainability Reporting Guide [35], which has been updated four times so far. The indicators proposed by different industries have been constructed from the primary and secondary dimensions to build a multiple indicator system. The World Economic Forum, in collaboration with Yale University and Columbia University, developed a multidimensional indicator system "Sustainability Index" [36], which has more than 20 primary indicators and 76 secondary indicators, including a total of five dimensional levels. The Cooperative Development Organization also carried out a comprehensive performance evaluation of the Canadian ecological environment [37], including the impact of transportation and electricity energy consumption on the environment, and the process of centralized treatment of urban waste. In addition, there are four other dimensions for comprehensive evaluation of Canada's overall environmental conditions.

China's natural resource asset audit evaluation system was gradually established after the trial implementation of the "Decision of the Central Committee of the Communist Party of China on Several Major Issues of Comprehensively Deepening Reform". For the selection of evaluation indicators, $\mathrm{Xu}$ Hong proposed that the design should be based on policies, funds, natural environment development and utilization of the natural resource [38]; Liu Baocai believes that the evaluation system should be constructed from the aspects of finance, implementation of policies and regulations [39]; Lin Zhonghua proposed to conduct audits from three dimensions of the implementation of natural resource asset laws policies, major decision-making matters, and natural resource asset management [40].

\subsubsection{Selection of Evaluation Area}

Since China has not yet established a mature natural resource asset audit system, and the natural resource endowments of each province are different. So the current application areas of the Natural Resources Asset Accountability Audit of Officials evaluation indicator system are often limited to certain provinces. Chen Chaobao, based in Jiaozhou City, took "policies, funds, projects, and supervision" as the entry point for the audit, and formulated 80 sub-items in seven categories in terms of the completion of the target accountability system [41]; Pan Wangming conducted audits on land resources, water resources, and forest resources based on Shaoxing City [42]; Ma Pin started from the quantity and quality of resources, policy formulation and implementation, resource protection management, resource development and utilization, and fund use, and based on these five aspects, con- 
structed an evaluation indicator system in Yunnan [43]; scholars such as Huang Rongbing analyzed the environmental problems faced by different main functional areas and believed that we should select the indicators which can reflect the pressure reduction to build a performance-oriented evaluation indicator system [44].

\subsubsection{Selection of Evaluation Method}

Some scholars believe that whether a region can achieve sustainable development is restricted by the characteristics of local natural resource endowments and the basic conditions of the ecological environment. Therefore, the Natural Resources Asset Accountability Audit of Officials should be carried out by constructing a regional environmental carrying capacity evaluation indicator system [45-47]; Qin Xiaoli based on the pressurestate-response model designed an evaluation system and the analytic hierarchy process method was used for comprehensive evaluation [48]; Li Suying also adopted the analytic hierarchy process method to compare the importance of each indicator in the evaluation system and determine the weight of the indicators, and then uses the fuzzy comprehensive evaluation method to evaluate each indicator, which intuitively shows the problems existing in the resource and environmental management of the audited area [49]; Zhang Lida uses the DeepLap neural network algorithm to extract satellite image feature information and combines with natural resource management planning maps for comparison and analysis [50].

Overall, for the selection of evaluation indicators, many scholars mainly concentrate on the following four categories: the first category is indicators from the legal and regulatory level, such as the Land Law of China; the second category is the indicators set by the authorities and local governments; the third category is indicators set by international organizations and social organizations, such as ISO; the fourth category is auditing standards and guidelines [51]. Regarding the choice of evaluation area, most scholars choose provinces with good natural resources conditions. Few scholars have made evaluations from the perspective of the national pilot zone for ecological conservation. Regarding the choice of evaluation method, most scholars use the expert scoring method to weight the indicators by comparing the relative importance of each indicator, and then use the analytic hierarchy process method for comprehensive scoring. However, considering that the results of the expert's scoring will have individual differences due to the different opinions of the experts, the subjectivity of this process will have an impact on the final scoring results.

The main marginal contribution of this paper lies in: First, this paper conducts an all-round evaluation of natural resource assets from three dimensions of energy subsystem, economic subsystem and environmental subsystem. Analogous to the definition of assets, this paper believes that natural resource assets in one area mainly refer to the collection of natural resources that can bring future economic benefits to the local people. From the three subsystems to evaluate the natural resource assets of a certain region, comprehensively consider the stock of natural resources, the economic benefits the natural resource can bring, which covers the two basic characteristics of the asset definition. Second, this paper introduces the entropy method into the Natural Resource Asset Accountability Audit of Officials evaluation system, which reduces the impact of subjectivity of the evaluation results and combined with the TOPSIS method for comprehensive evaluation. Third, this paper applies the evaluation system to Jiangxi Province, one of the national pilot zones for ecological conservation in China. As the first batch of national ecological civilization experimental zone, Jiangxi Province adheres to the strategic positioning of building a "Jiangxi model" of China, and unswervingly follows the path of ecological priority and green development. In recent years, it has achieved a series of remarkable achievements in natural resource protection and ecological governance. Applying the Natural Resources Asset Accountability Audit of Officials evaluation indicator system to Jiangxi Province can help to deeply analyze the driving factors of its ecological performance improvement and play a demonstrative role for other provinces in China to reach the sustainable development 
model of natural resource assets, which also reflects the original intention of establishing a national ecological civilization experimental zone in China.

\section{Methods and Indicator Selection}

\subsection{Entropy Weight Method}

The weighting method of a comprehensive evaluation model can be mainly divided into subjective weighting method and objective weighting method. The subjective weighting method mainly includes comparative weighting method, analytic hierarchy process and expert scoring method, but its evaluation result will be disturbed by individual subjectivity and lacks objectivity. Objective weighting method mainly includes principal component analysis method, entropy weight method and mean square deviation method. It mainly calculates the weight according to the nature of the evaluation indicator data, which can deeply reflect the discrimination ability of the indicator.

Entropy weight method mainly calculates the information entropy according to the variation degree of each indicator, and then weights each evaluation indicator. The concept of entropy was first introduced into information theory from thermodynamics by C.E. Shannon. The amount of information entropy represents the dispersion of data. The smaller the dispersion, the less information it contains, and the lower the weight is given to the indicator [52]. If an indicator is the same value for all samples, the weight of this indicator should be 0 , because this indicator cannot reflect the difference of each evaluation sample.

\subsubsection{Standardized Data}

For efficiency-based indicators, use the Formular (1) to standardize; for cost-based indicators, use the Formular (2) to standardize. The formula is as follows:

$$
\begin{aligned}
x_{i j}^{\prime} & =\frac{x_{i j}-\min x_{i j}}{\max x_{i j}-\min x_{i j}} \\
x_{i j}^{\prime} & =\frac{\max x_{i j}-x_{i j}}{\max x_{i j}-\min x_{i j}}
\end{aligned}
$$

In Formulars (1) and (2), $x_{i j}$ is the original value of the $j$ th indicator in year $i$, and $x_{i j}^{\prime}$ is the standardized value. $i=1,2, \ldots, m$ ( $m$ is the number of evaluation years); $j=1,2, \ldots, n$ ( $n$ is the number of evaluation indicators).

\subsubsection{Normalization of Indicators}

Normalization is to eliminate the influence of the different dimensions of each indicator, so that all the data fall within the [0,1] interval, which is convenient for comparison between different indicators. The matrix after normalization is $X$, the elements of which are $X_{i j}$ :

$$
X_{i j}=\frac{x_{i j}^{\prime}}{\sum_{i=1}^{n} x_{i j}^{\prime}}
$$

\subsubsection{Calculate Information Entropy $e_{j}$}

The information entropy $e_{j}$ reflects the amount of information contained in the evaluation indicators. The larger the information entropy, the more the amount of information displayed by the indicator. $\left(0 \leq e_{j} \leq 1\right)$ (If $X_{i j}=0$, define $X_{i j} \times \ln X_{i j}=0$ ).

$$
e_{j}=-\frac{1}{\ln n} \sum_{j=1}^{n}\left(X_{i j} \times \ln X_{i j}\right)
$$

2.1.4. Calculate Difference Coefficient $g_{i}$ and Indicator Weight $w_{j}$

$$
g_{j}=1-e_{j}
$$




$$
w_{j}=\frac{g_{j}}{\sum_{j=1}^{m} g_{j}}
$$

\subsection{Technique for Order Preference by Similarity to an Ideal Solution}

TOPSIS method is a common comprehensive evaluation method, which first constructs the optimal and inferior solutions of the evaluation system, and then calculates the relative proximity of each evaluation object to the ideal solution (optimal and inferior solutions), then judge the performance of each evaluation object.

\subsubsection{Construct Entropy Weight Decision-Making Matrix $V$}

The entropy weight decision-making matrix $V$ is constructed using the weights of each indicator determined by the entropy weight method, where the element is $V_{i j}$ :

$$
V_{i j}=W_{j} X_{i j}
$$

\subsubsection{Calculate the Ideal Solution and Proximity}

The larger the value of the element $V_{i j}$ in the decision matrix $V$, the better the solution. Define the ideal solution (maximum value) $V^{+}$and the negative ideal solution (minimum value) $V^{-}$:

$$
\begin{aligned}
& V^{+}=\left(V_{1}^{+}, V_{2}^{+}, \ldots, V_{m}^{+}\right)=\left\{\max V_{i j} \mid j=1,2, \ldots, m\right\} \\
& V^{-}=\left(V_{1}^{-}, V_{2}^{-}, \ldots, V_{m}^{-}\right)=\left\{\min V_{i j} \mid j=1,2, \ldots, m\right\}
\end{aligned}
$$

The distance $S_{i}^{+}$between the $i$ th $(i=1,2, \ldots, n)$ evaluation object and the ideal solution (maximum value), and the $i$ th $(=1, \ldots, n)$ evaluation object and the negative ideal solution, the (minimum) distance $S_{i}^{-}$.

$$
\begin{aligned}
& S_{i}^{+}=\sqrt{\sum_{j=1}^{m}\left(V_{j}^{+}-V_{i j}\right)^{2}} \\
& S_{i}^{-}=\sqrt{\sum_{j=1}^{m}\left(V_{j}^{-}-V_{i j}\right)^{2}}
\end{aligned}
$$

Calculate the proximity $C_{i}$ of the $i$ th $(i=1,2, \ldots, n)$ evaluation object. $0 \leq C_{i} \leq 1$. The larger $C_{i}$ is, the smaller $S_{i}^{+}$is, that is, the closer it is to the ideal solution.

$$
C_{i}=\frac{S_{i}}{S_{i}^{+}+S_{i}^{-}}
$$

\subsection{Indicator Selection}

The concept of natural resource assets is different from the natural resources in the traditional sense, which can be broadly defined as the set of all resources in an administrative area. First, they are owned or controlled by the state, second, they are expected to bring an inflow of future economic benefits to the state and the people, and third, they are a general term for various elements of material wealth in nature that can be measured in money [53]. SEEA 2012 accounting for natural resources covers mineral resources, water resources, forest resources, land resources, and other biological resources [54].

In order to conduct an overall audit of the natural resource assets of leading officials, the evaluation system constructed in this paper will cover natural resources such as land, forest, mineral, and water resources. This paper will establish a $3 \mathrm{E}$ model to assess the status of natural resource assets in three dimensions: energy subsystem, economic subsystem, and environmental subsystem. The energy subsystem mainly assesses the stock of natural resources assets, including 22 indicators such as total water resources, forest area, forest 
accumulation, arable land area and mineral resources stock; the economic subsystem mainly assesses the economic benefits generated by each natural resource, including 12 indicators such as water consumption per 10,000 Yuan GDP, hydroelectric power generation, forestry output value and mining output value; the environment subsystem mainly assesses local environmental management, environmental quality, ecological protection, green living and other aspects. The environmental subsystem mainly assesses the local environmental governance, environmental quality, ecological protection and other aspects, including sewage discharge, forest coverage, industrial sulfur dioxide emissions, industrial nitrogen oxide emissions, PM2.5 (particulate matter in the atmosphere with a diameter of 2.5 microns or less) concentration and other 18 indicators, and the evaluation indicators system is shown in Figure 2, and the detail information such as the unit of the indicator is shown in the Appendix A Table A1.

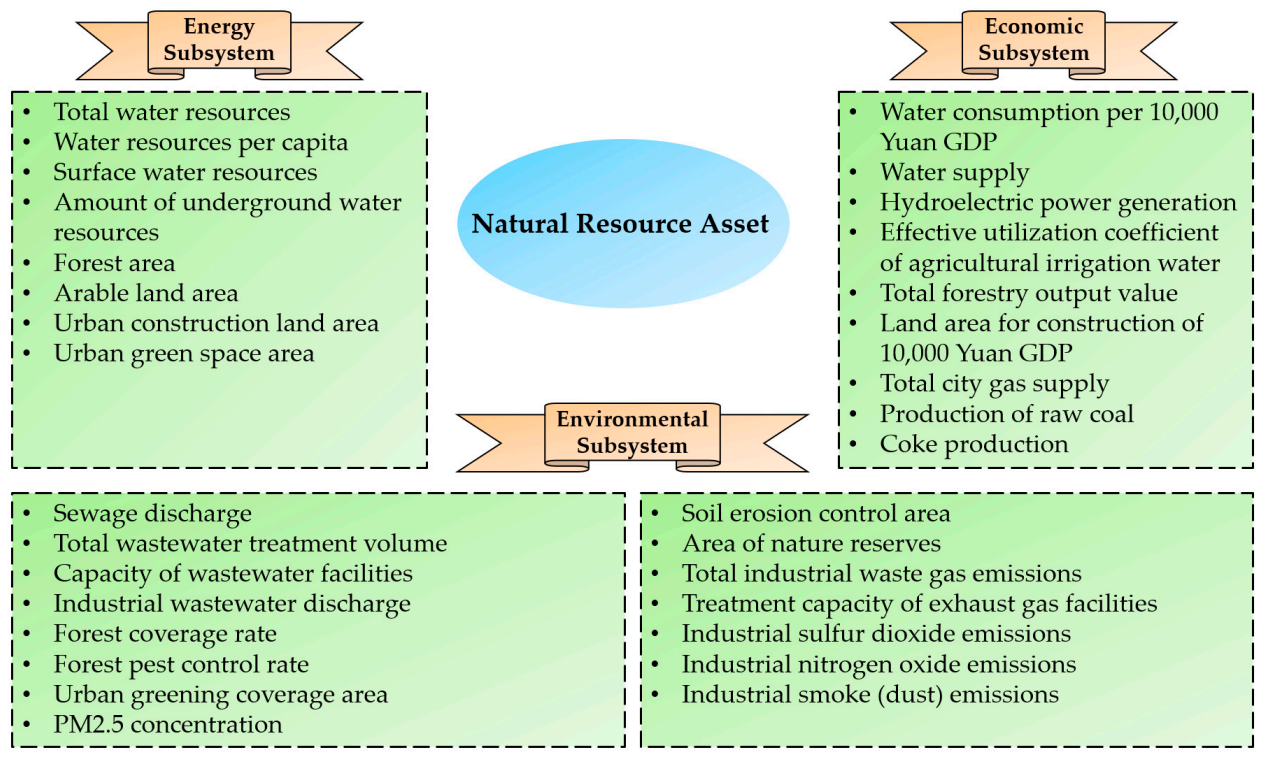

Figure 2. Natural resource asset accountability audit of officials' evaluation indicators.

The main indicators of the natural resources accountability audit of officials are denoted by $C=\left(C_{1}, C_{2}, \ldots, C_{m}\right)$, and each main-level indicator $C m$ has $n$ sub-indicators, denoted by $C_{m n}=\left(C_{m 1}, C_{m 2}, \ldots, C_{m n}\right)$, where $C_{m n}$ denotes the $n$th sub-indicator under the mth main indicator. Firstly, the entropy weighting method is used to assign weights to each indicator based on the information entropy of different indicators, and then the TOPSIS method is used to comprehensively evaluate the status of natural resource assets each year.

\section{Application in National Pilot Zone for Ecological Conservation in China}

\subsection{Study Area}

Jiangxi Province is located between $24^{\circ} 29^{\prime} 14^{\prime \prime}$ to $30^{\circ} 04^{\prime} 41^{\prime \prime}$ north latitude and $113^{\circ} 34^{\prime} 36^{\prime \prime}$ to $118^{\circ} 28^{\prime} 58^{\prime \prime}$ east longitude (Figure 3). It is located in southeastern China with a total area of 166,900 square kilometers in 2019 . It is dominated by mountainous hills, narrow in the north and wide in the south. 


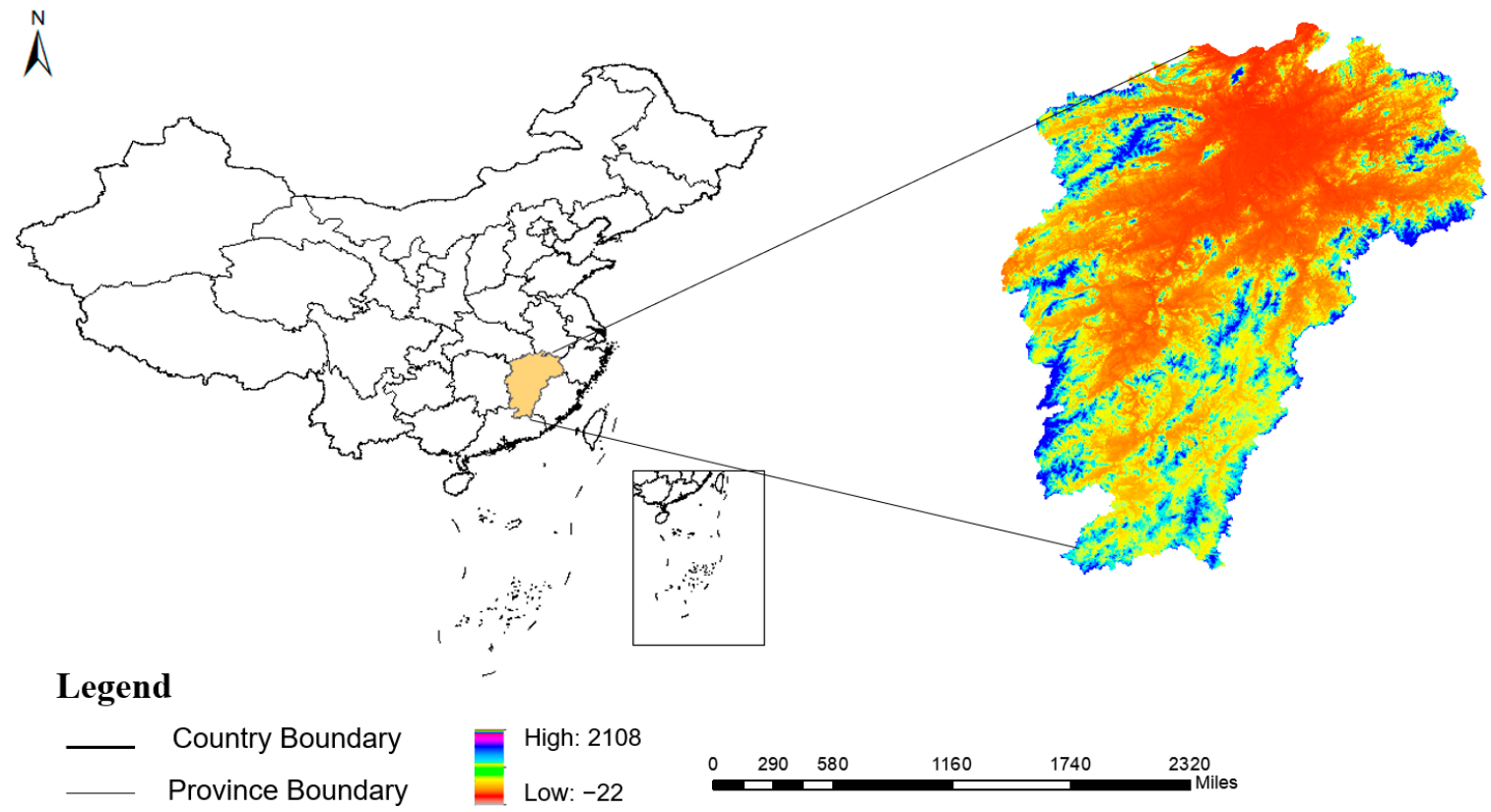

Figure 3. Location and Digital Elevation Model of Jiangxi Province in 2020.

Since the China's Central Committee passed the "Pilot Plan for the Development of Natural Resources Accountability Audit of Officials" [55] in July 2015, various parts of the country have carried out the natural resources accountability audit of officials policy based on their own conditions. Jiangxi Province has successively deployed natural resources accountability audit of officials. Taking into account that since the construction of the first batch of national pilot zones for ecological conservation in China, the quality of Jiangxi's ecological environment has been continuously improved on a high-level basis, taking the lead in realizing the "National Forest City" and "National Garden City", and 35 ecological civilization pilot reforms results are included in the national promotion list. Therefore, this article chooses Jiangxi Province as the blueprint, scores the natural resource assets management performance of the leading officials in Jiangxi Province.

\subsection{Data Source}

Taking into account the availability of data, this article mainly evaluates the management of natural resource assets by leading officials in Jiangxi Province from 2015 to 2019 from the three dimensions of energy subsystem, economic subsystem, and environmental subsystem based on 32 indicators. The following data mainly come from the China National Bureau of Statistics and the Jiangxi Provincial Statistical Yearbook.

\subsection{Basic Overview of Resources, Environment and Economy in Jiangxi Province \\ 3.3.1. Natural Resources Overview}

Land resource situation: The total land area of the province is 16 million square meter, of which arable land is 3.7 billion square meters, accounting for $18.52 \%$; garden land is 4,764,300 mu, accounting for $1.90 \%$; woodland is $154.5257 \mathrm{million} \mathrm{mu}$, accounting for $61.71 \%$; grassland is 4.0306 million mu, accounting for $1.61 \%$ of urban, village and industrial and mining land 14.19 million acres, accounting for $5.96 \% ; 3.769$ million acres of land for transportation, accounting for $1.51 \% ; 18,749,400$ acres of land for water and water conservancy facilities, accounting for 7.49\%; and 3.263 million acres of other land, accounting for $1.30 \%$. Figure 4 shows main types of land resources in Jiangxi Province. 


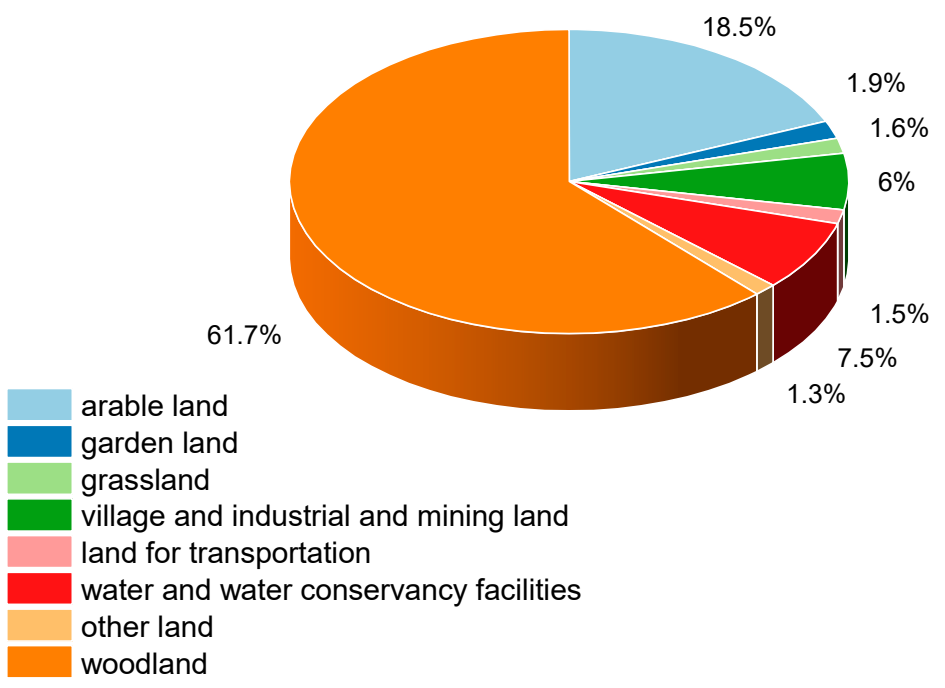

Figure 4. The main types of land resources in Jiangxi Province. Data source: Jiangxi Provincial Statistical Yearbook 2020 [56].

The situation of mineral resources: Jiangxi province is one of the main non-ferrous, and rare earth mineral bases in the country, and holds 34.78 million tons of wollastonite mine with the largest reserves in the world so far. In 2019, Jiangxi Province maintained 193 kinds of minerals; as many as 153 kinds of minerals with relatively large reserves have been identified.

Overview of water resources: The total amount of water resource in Jiangxi Province is 114.09 billion cubic meters, the total runoff of surface water resources is 112.985 billion cubic meters, and the total rechargeable groundwater resources is 29.854 billion cubic meters. It has the largest freshwater lake in the country and more than 160 rivers with water throughout the year. The volume of water resources is relatively abundant.

Overview of forest resources: The total land area of Jiangxi Province is 16.695 million square kilometers, of which 10.720 million square kilometers are used for forestry in the province, accounting for $64.2 \%$; the forest coverage rate is $63.1 \%$. Among the forest resources, the area of forest land is 9.185 million square kilometers, the area of sparse forest land is 112,000 square kilometers, the area of uncultivated forest land is 230,000 square kilometers, and the nursery land is 3 thousand square kilometers. In recent years, Jiangxi Province has issued the "Government Work Report" to continuously promote the closure of hills for afforestation and the conversion of farmland to forests, and the province's forest coverage rate has continued to stabilize at around $63-64 \%$.

\subsubsection{Economy Overview}

The permanent population of Jiangxi Province in 2019 was 46.661 million, an increase of 186,000 over the end of the previous year. Among them, the urban permanent population was 26.793 million, accounting for $57.4 \%$ of the total population, and the rural permanent population was 19.868 million, accounting for $42.6 \%$ of the total population. The total GDP was 2475.75 billion yuan, at a growth rate of $8.98 \%$.

In 2019, the total budget expenditure of Jiangxi Province was 640.26 billion yuan, an increase of $13 \%$; taxation accounted for $81.5 \%$ of fiscal revenue and $70.3 \%$ of general public budget revenue. The comparison of economic development in the past five years is as Figure 5 shows: 


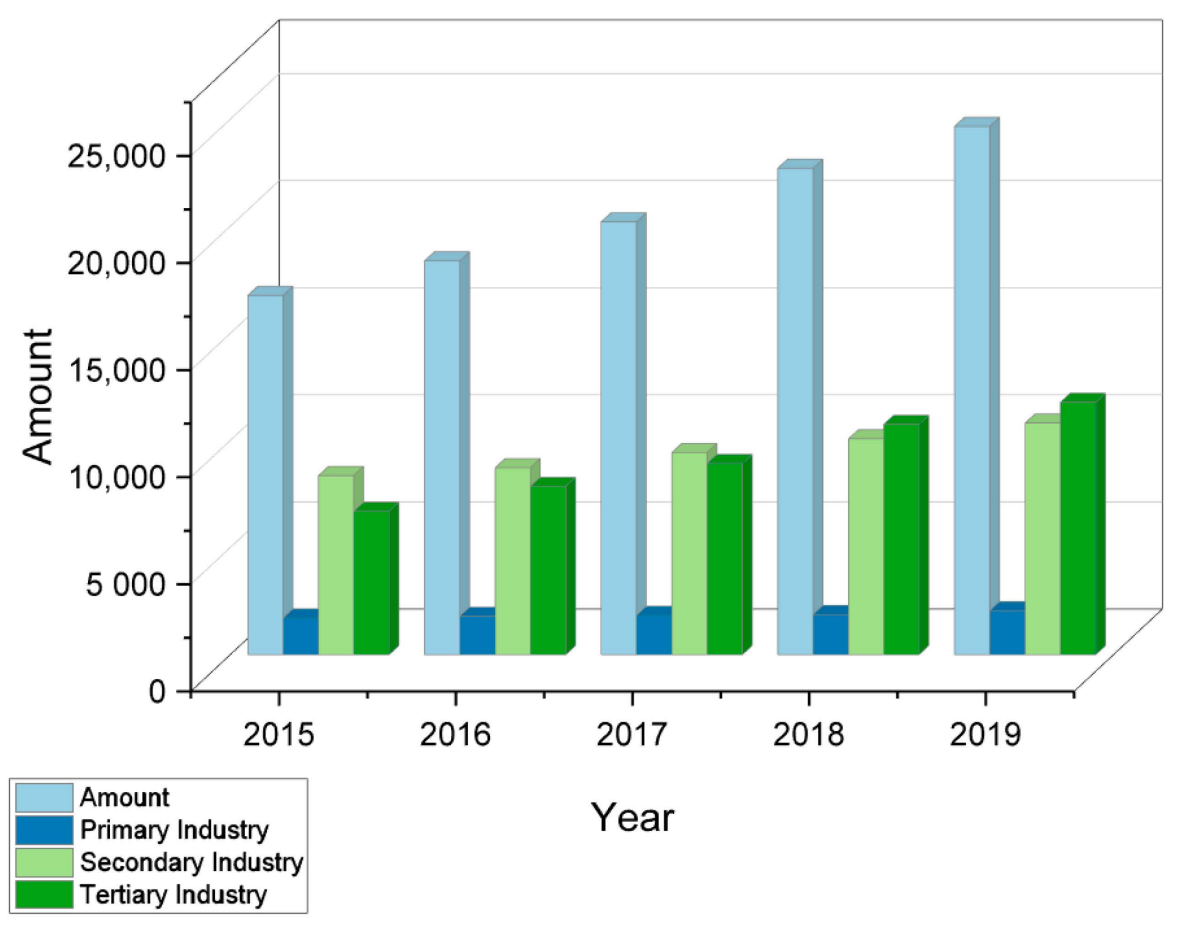

Figure 5. 2015-2019 Economic development industry change trend chart (100 million). Data source: Jiangxi Provincial Statistical Yearbook 2015-2019 [56].

\subsection{The Application of the Evaluation System in Jiangxi Province}

\subsubsection{Land Resources}

The Jiangxi Government has continued to promote land reform and planning revisions. At the beginning of 2019, the State Council's approval of major project construction land applications has dropped by 59\% year-on-year, and more than 10 major project demonstrations have been accelerated, which improves the efficiency of construction land use and strengthens land protection management. The application base of land resource evaluation indicators as the Table 1 shows:

Table 1. Application base of land resource evaluation indicators.

\begin{tabular}{cccccc}
\hline Indicator & $\mathbf{2 0 1 5}$ & $\mathbf{2 0 1 6}$ & $\mathbf{2 0 1 7}$ & $\mathbf{2 0 1 8}$ & $\mathbf{2 0 1 9}$ \\
\hline Cultivated land area & 3083 & 3082 & 3086 & 3090 & 3090 \\
Urban construction land area & 1231 & 1279 & 1403 & 1477 & 1561 \\
Urban garden green area & 54,147 & 56,768 & 637,47 & 69,708 & 71,933 \\
Soil erosion control area & 5578 & 5675 & 5787 & 5918 & 6070 \\
Area of nature reserve & 123 & 107 & 106 & 110 & 108
\end{tabular}

Note. The units of Cultivated land area, Urban construction land area, Urban garden green area, Soil erosion control area, Area of nature reserve are ten thousand $\mathrm{mu}$, ten thousand square kilometers, hectares, thousand hectares and ten thousand hectares.

\subsubsection{Forest Resources}

The national land greening resources bulletin of Jiangxi Province shows that the quality of forest resources in Jiangxi Province is still steadily improving. In recent years, Jiangxi Province has made great progress in the construction of ecological civilization. The success of the construction of ecological civilization cities has further increased the amount of urban forest resources in Jiangxi Province. Great progress has been made in forest ecological poverty alleviation, and forest coverage has been further stabilized. The application base of forest resource evaluation indicators as the Table 2 shows: 
Table 2. Application base of forest resource evaluation indicators.

\begin{tabular}{cccccc}
\hline Indicator & $\mathbf{2 0 1 5}$ & $\mathbf{2 0 1 6}$ & $\mathbf{2 0 1 7}$ & $\mathbf{2 0 1 8}$ & $\mathbf{2 0 1 9}$ \\
\hline Forest area (ten thousand hectares) & 1002 & 1002 & 1002 & 1021 & 1021 \\
Forestry output value (100 million yuan) & 271 & 295 & 296 & 320 & 343 \\
Forest coverage (\%) & $63 \%$ & $60 \%$ & $63 \%$ & $63 \%$ & $61 \%$ \\
Forest pest control rate (\%) & $54 \%$ & $69 \%$ & $87 \%$ & $93 \%$ & $75 \%$ \\
Urban green coverage area (hectares) & 58,510 & 61,259 & 69,027 & 75,471 & 77,590 \\
\hline
\end{tabular}

\subsubsection{Water Resources}

Since Jiangxi Government set up the "Three Red Lines" control indicators, all the districts and cities in the province have reached the red line indicators. The water consumption per 10,000 yuan of GDP in Jiangxi Province in 2019 is 114 cubic meters, a decrease of $26.0 \%$ from 2015; the effective coefficient of agricultural irrigation is 0.509 , Higher than the annual planning target. In addition, the water quality compliance rate of the $178 \mathrm{important}$ national rivers and lakes water function areas included in the assessment was $97.7 \%$, far exceeding the annual red line indicator. The application base of water resource evaluation indicators as the Table 3 shows:

Table 3. Application base of water resources evaluation indicators.

\begin{tabular}{cccccc}
\hline Indicator & $\mathbf{2 0 1 5}$ & $\mathbf{2 0 1 6}$ & $\mathbf{2 0 1 7}$ & $\mathbf{2 0 1 8}$ & $\mathbf{2 0 1 9}$ \\
\hline Total water resources & 2001 & 2221 & 1655 & 1149 & 2052 \\
Water resources per capita & 4395 & 4851 & 3593 & 2479 & 4405 \\
Surface water resources & 1983 & 2203 & 1637 & 1130 & 2033 \\
Groundwater resources & 465 & 502 & 379 & 299 & 482 \\
Water consumption per 10,000 of GDP & 147 & 134 & 119 & 114 & 102 \\
Water supply volume & 246 & 245 & 248 & 251 & 253 \\
Hydroelectric power generation & 178 & 199 & 144 & 121 & 168 \\
Water effective utilization coefficient & 0.490 & 0.495 & 0.503 & 0.509 & 0.531 \\
Sewage discharge & 88,945 & 88,768 & 91,989 & 99,678 & 103,662 \\
Total sewage treatment & 78,041 & 78,988 & 87,055 & 94,629 & 97,724 \\
Industrial wastewater discharge & 76,913 & 54,786 & 41,207 & 39,556 & 39,000
\end{tabular}

Note. The units of the indicators above are 100 million cubic meters, cubic meters/person, 100 million cubic meters, 100 million cubic meters, cubic meters/yuan, 100 million cubic meters, 100 million kilowatt hours, ten thousand cubic meters, ten thousand cubic meters, 10,000 tons.

\subsubsection{Mineral Resources}

By 2019, there were a total of 10 national-level integrated exploration areas in the province, which hold the world's largest reserves of wollastonite and fluorite mines so far. The total number of mines in Jiangxi Province is 3582, of which 95 are large-scale mines, 66 are medium-sized mines, and 3421 are small-scale mines. From 2018 to 2019, the province's mining volume was 355 million tons, the total mining output value was 34.699 billion yuan, and the total profit was 3.334 billion yuan. In 2019, the ratio of 10,000 yuan of GDP to minerals was $0.13 \%$, which was a large decline compared to previous years. This also shows that Jiangxi Province's industrial structure reform has achieved great results.

\subsubsection{Atmospheric Conditions}

In 2019, the emissions of sulfur dioxide and nitrogen oxides in Jiangxi Province were reduced by $10.17 \%$ and $9.63 \%$ over 2015 , and carbon dioxide emissions per unit of GDP fell by more than $2.5 \%$. The environmental condition is still at the forefront of the country, and the ecological environment air quality is generally excellent. The application base of atmospheric environmental evaluation indicators as the Table 4 shows: 
Table 4. Application base of atmospheric environmental evaluation indicators.

\begin{tabular}{cccccc}
\hline Indicator & $\mathbf{2 0 1 5}$ & $\mathbf{2 0 1 6}$ & $\mathbf{2 0 1 7}$ & $\mathbf{2 0 1 8}$ & $\mathbf{2 0 1 9}$ \\
\hline Total industrial waste gas emissions & 17,055 & 15,162 & 15,065 & 15,519 & 15,623 \\
Waste gas treatment facility capacity & 33,006 & 32,659 & 389,311 & 496,421 & 496,421 \\
Industrial sulfur dioxide emissions & 515,662 & 262,705 & 200,768 & 151,607 & 151,607 \\
Industrial nitrogen oxide emissions & 279,428 & 208,721 & 195,180 & 189,857 & 189,857 \\
Industrial smoke (dust) emissions & 446,013 & 301,340 & 257,163 & 209,781 & 209,781 \\
PM2.5 concentration & 43 & 45 & 46 & 38 & 35 \\
\hline
\end{tabular}

\subsubsection{Determine the Weight Based on the Entropy Method}

In order to eliminate the impact of the different types of indicators on the evaluation results, the indicators are first standardized using Formulars (1) and (2). Then calculate the information entropy $e_{j}$ and difference coefficient of each indicator $g_{j}$ and indicators weight $w_{j}$, and finally get the weight of each indicator as shown in Table 5.

Table 5. Indicators' entropy and weight.

\begin{tabular}{|c|c|c|c|}
\hline Primary Indicator & Secondary Indicator & $e_{j}$ & $w_{j}$ \\
\hline \multirow{8}{*}{ Energy subsystem } & Total water resources (100 million cubic meters) & 0.841 & 0.020 \\
\hline & Water resources per capita $\left(\mathrm{m}^{3} /\right.$ person $)$ & 0.841 & 0.020 \\
\hline & Surface water resources (billion cubic meters) & 0.841 & 0.020 \\
\hline & Amount of underground water resources (billion cubic meters) & 0.831 & 0.022 \\
\hline & Forest area (million hectares) & 0.431 & 0.073 \\
\hline & Arable land area $(10,000 \mathrm{mu})$ & 0.712 & 0.037 \\
\hline & Urban construction land area $(10,000$ square kilometers $)$ & 0.763 & 0.030 \\
\hline & Urban green space area (hectares) & 0.762 & 0.030 \\
\hline \multirow{9}{*}{ Economic subsystem } & Water consumption per 10,000 Yuan GDP (cubic meters) & 0.811 & 0.024 \\
\hline & Water supply (billion cubic meters) & 0.689 & 0.040 \\
\hline & Hydroelectric power generation (billion kilowatt hours) & 0.813 & 0.024 \\
\hline & Effective utilization coefficient of agricultural irrigation water & 0.719 & 0.036 \\
\hline & Total forestry output value (billion yuan) & 0.797 & 0.026 \\
\hline & Land area for construction of 10,000 Yuan GDP $\left(\mathrm{km}^{2}\right)$ & 0.823 & 0.023 \\
\hline & Total city gas supply (billion cubic meters) & 0.770 & 0.029 \\
\hline & Production of raw coal (million tons) & 0.638 & 0.046 \\
\hline & Coke production (million tons) & 0.687 & 0.040 \\
\hline \multirow{15}{*}{ Environmental subsystem } & Sewage discharge $\left(\right.$ million $\left.\mathrm{m}^{3}\right)$ & 0.804 & 0.025 \\
\hline & Total wastewater treatment volume (million cubic meters) & 0.702 & 0.038 \\
\hline & Capacity of wastewater facilities (million cubic meters/day) & 0.623 & 0.048 \\
\hline & Industrial wastewater discharge (million tons) & 0.848 & 0.019 \\
\hline & Forest coverage rate $(\%)$ & 0.823 & 0.023 \\
\hline & Forest pest control rate $(\%)$ & 0.820 & 0.023 \\
\hline & Urban greening coverage area (ha) & 0.761 & 0.031 \\
\hline & Soil erosion control area (thousand hectares) & 0.773 & 0.029 \\
\hline & Area of nature reserves (million hectares) & 0.473 & 0.068 \\
\hline & Total industrial waste gas emissions (million cubic meters) & 0.856 & 0.019 \\
\hline & Treatment capacity of exhaust gas facilities (million $\mathrm{m}^{3} / \mathrm{h}$ ) & 0.680 & 0.041 \\
\hline & Industrial sulfur dioxide emissions (tons) & 0.855 & 0.019 \\
\hline & Industrial nitrogen oxide emissions (tons) & 0.859 & 0.018 \\
\hline & Industrial smoke (dust) emissions (tons) & 0.850 & 0.019 \\
\hline & PM2.5 concentration $\left(\mu \mathrm{g} / \mathrm{m}^{3}\right)$ & 0.698 & 0.039 \\
\hline
\end{tabular}

\section{Results and Discussion}

\subsection{The Overall Performance of Jiangxi Province from 2015 to 2019}

This paper applies the Natural Resources Asset Accountability Audit of Officials evaluation system based on the Entropy-TOPSIS method to Jiangxi Province, one of the first batch of national ecological civilization experimental areas in China. The evaluation results (Table 6) show that during 2015-2019, the closeness between the status of natural resources assets in Jiangxi Province and the optimal solution increased from 0.453 to 0.583 , and constantly approached 1 . This result indicates that in response to the "Pilot Plan for the Implementation of the Natural Resources Asset Accountability Audit of Officials" adopted 
by the Central Committee for Comprehensively Deepening Reform in 2015, after Jiangxi Province began to deploy a Natural Resources Asset Accountability Audit of Officials, in the period from 2015 to 2019, Jiangxi government has performed well in fulfilling their natural resource asset management responsibilities, and has achieved good results in ecological environment construction, and the overall natural resource situation has shown a steady upward trend. Although there is still room for improvement in the management process, the overall performance should be affirmed.

Table 6. 2015-2019 evaluation results.

\begin{tabular}{cccccc}
\hline Year & $\mathbf{2 0 1 5}$ & $\mathbf{2 0 1 6}$ & $\mathbf{2 0 1 7}$ & $\mathbf{2 0 1 8}$ & $\mathbf{2 0 1 9}$ \\
\hline$C_{i}$ & 0.453 & 0.436 & 0.461 & 0.557 & 0.583 \\
\hline
\end{tabular}

By comparing the distance $S+$ between the state of natural resource assets in Jiangxi Province and the optimal solution and the distance $S-$ between the worst solution in 2015-2019 (Figure 6), it can be seen that the distance between the state of natural resource assets in Jiangxi Province and the optimal solution is decreasing year by year. The overall distance from the worst solution shows an increasing trend, which indicates that the state of natural resource assets in Jiangxi Province is constantly approaching the optimal solution and far away from the worst solution.

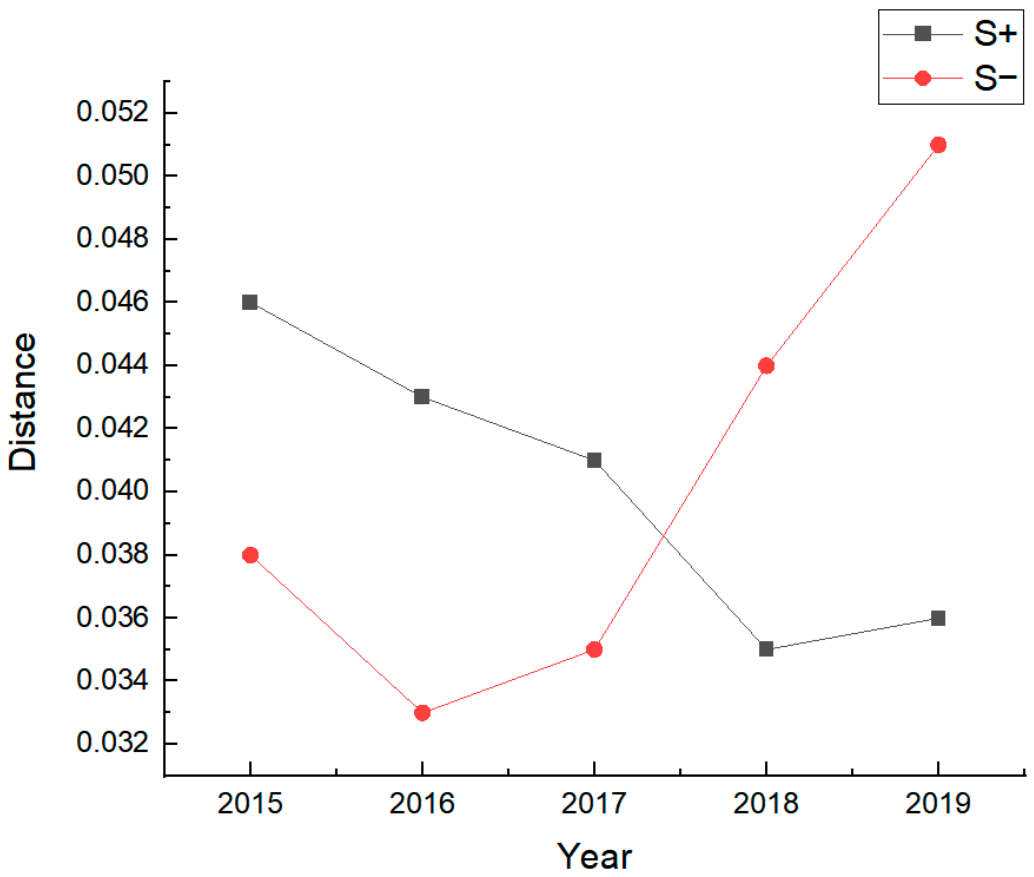

Figure 6. The value of the S+ and S- during 2015 to 2019.

\subsection{Analysis of Weight}

In order to further analyze the reasons for the improvement of natural resource assets in Jiangxi Province, the main driving system that changes the evaluation score can be analyzed based on the weight of the indicators. Considering that the principle of the entropy method is to reflect the amount of information contained in the evaluation indicators according to the degree of variation of the evaluation indicators, the more information the indicators is given the higher the weight. In the process of using the entropy method to evaluate natural resource assets in Jiangxi Province from 2015 to 2019, the comprehensive weight (Figure 7) assigned to the environmental subsystem is 0.458 , while the respective weights of the energy subsystem and the economic subsystem are 0.253 and 0.289 . This reflects that during the period 2015-2019, the indicators' values in 
the environmental subsystem of Jiangxi Province have undergone substantial changes. In the evaluation system, the weighted top five indicators are forest area, nature reserve area, wastewater treatment facility capacity, raw coal production, and waste gas treatment facility capacity. The nature reserve area, wastewater treatment facility capacity and waste gas treatment capacity belong to the environmental subsystem. The indicators' values in the environmental subsystem have changed a lot within five years, leading to a higher comprehensive weight, which reveals that Jiangxi Province has achieved significant improvement in environmental governance during 2015-2019.

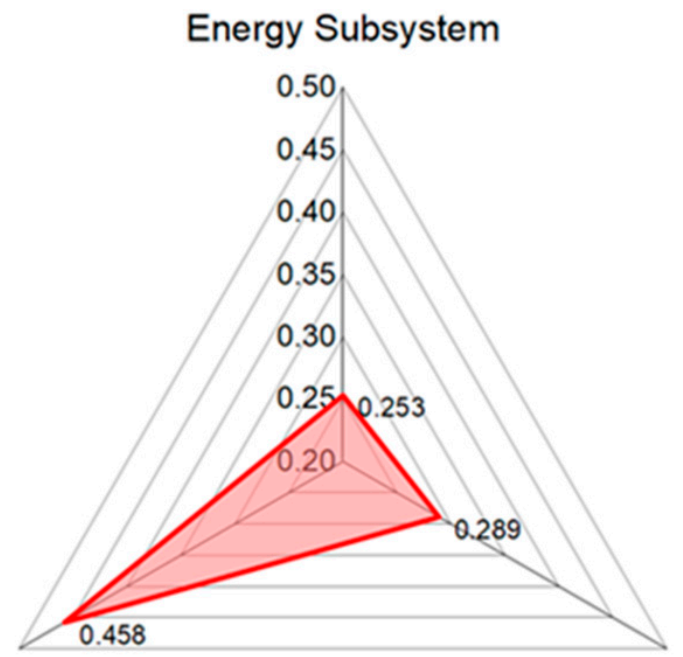

\section{Environmental Subsystem}

\section{Economic Subsystem}

Figure 7. The comprehensive weight of the subsystems.

\subsection{Analysis of Three Subsystems}

By analyzing the scores of the three major subsystems of energy, economy, and environment during 2015-2019 (Figure 8), it can be seen that the score of the environmental subsystem has increased year by year, from 0.30 in 2015 to 0.73 in 2019, an increase of 140\%. The score of the economic subsystem shows a downward trend, from 0.62 in 2015 to 0.39 in 2019. The resource subsystem fluctuates in different trends every year. After understanding the overall performance of each of the three subsystems, it is necessary to conduct a specific analysis of the indicators in each system to find the driving indicators for the improvement of the natural resource asset situation in Jiangxi Province.

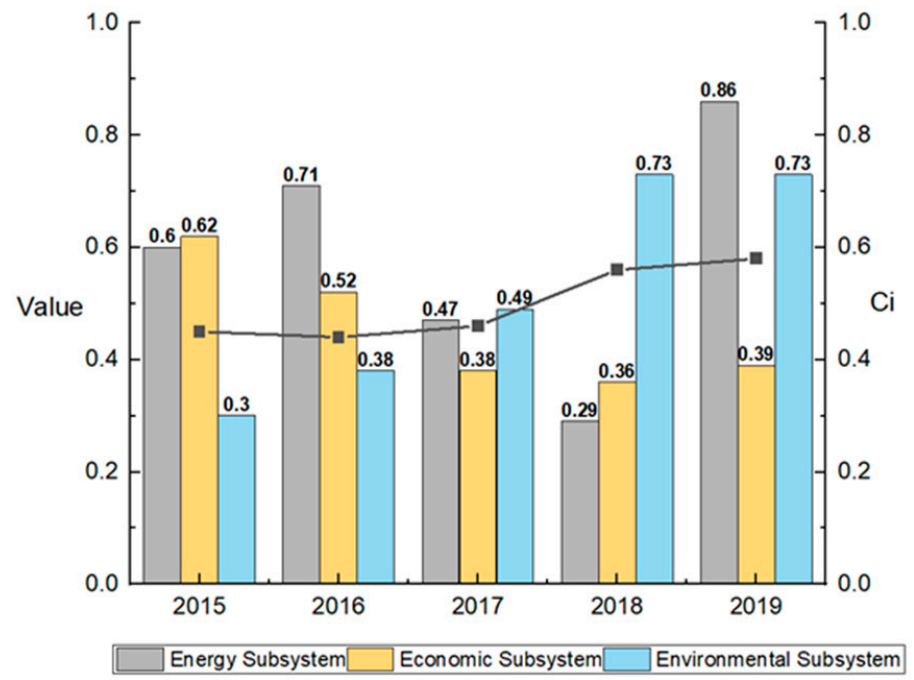

Figure 8. The Performance of the Subsystems during 2015 to 2019. 
The main reason for the continuous increase in the score of the environmental subsystem is the overall increase in the treatment capacity of wastewater facilities, forest pest control rates, urban green coverage and waste gas treatment facilities capacity in Jiangxi Province in the past five years, as well as industrial wastewater discharge and soil erosion control. The industrial sulfur dioxide emissions, industrial nitrogen oxide emissions, industrial smoke (dust) emissions and PM2.5 concentration show a downward trend. In particular, indicators related to air pollutant emissions have improved significantly. Compared with 2015, Jiangxi's industrial sulfur dioxide emissions decreased by $71 \%$ in 2019 , industrial nitrogen oxide emissions decreased by $30 \%$, and industrial smoke (dust) emissions decreased by 53\%. The $\mathrm{PM}_{2.5}$ concentration dropped by $19 \%$, reflecting the remarkable results achieved in the atmospheric governance of Jiangxi Province. This is mainly attributable to Jiangxi Province's solid promotion of desulfurization, stock removal, and dust removal transformation in key industries. Jiangxi Province has implemented classified policies for key factors affecting air quality, and vigorously promoted dust removal, coal control, emission reduction, and emission compliance. In addition, it has strengthened scientific and technological support, created an air pollution intelligent management platform, real-time dispatch and command the province's air pollution control work, and continuously improve the level of scientific and precise pollution control. In addition, the Jiangxi Provincial Department of Ecology and Environment insists on publishing daily air quality rankings of cities with districts, preparing weekly briefings on pollution prevention and control, monthly reporting on air quality conditions across the province, and holding quarterly air pollution prevention and control work scheduling meetings. Special teams keep an eye on the hourly data of national-controlled air quality stations, and broadcast hourly during the sprint, forming a set of happy working mechanisms, making Jiangxi Province the first in the central provinces in terms of ambient air quality.

The reason for the decline in the performance of the economic subsystem lies in the continuous decline in hydroelectric power generation, raw coal production, coke production and water consumption per 10,000 yuan of GDP, as well as the increase in the total output value of forestry. Compared with 2015, the water consumption per 10,000 yuan of GDP in Jiangxi Province in 2019 has dropped by about 31\%, which reflects the improvement in economic benefits brought by water resources in Jiangxi Province. However, Jiangxi Province's raw coal production, coke production, and hydroelectric power generation have declined, resulting in a decline in the score of the economic subsystem. However, considering that China adheres to the new development concept of "innovation, coordination, green, openness, and sharing" and promotes the continuous transformation of the economy towards high-quality development and low-carbon development, the reason for this change is likely to be caused by the change in the energy structure of Jiangxi Province. The increase in the use of clean energy, such as natural gas, has led to a decline in the demand for raw coal and coke, which in turn led to a decline in its production.

The main reason for the continuous fluctuation of the energy subsystem is that the stock of water resources in Jiangxi Province has fluctuated during the five years. The stock of water resources has increased during 2015-2016, but it has been declining during 2016-2018, and has rebounded in 2019. Per capita water resources are similar to the changes in the stock of surface water resources. In addition to water resources, the situation in Jiangxi Province is optimistic in other respects. The area of forest and arable land, as well as the area of urban gardens and green areas, is showing an upward trend.

\section{Conclusions and Recommendations}

\subsection{Conclusions}

The actual application of the Natural Resources Asset Accountability Audit of Officials evaluation system not only has enlightenment for the Jiangxi Province, but also contributes ideas to the natural resource asset audit system for leading officials in other provinces across the country. On the one hand, this paper starts with the scientific and comprehensive indicators and builds an evaluation system based on the three subsystems of Energy, 
Environment, and Economy, which not only takes into account the attributes of natural resources themselves, but also takes into account their economic effect and the ability of leading officials to govern the environment. On the other hand, in order to enhance the objectivity of the evaluation system, this paper introduces the combination of entropy method and TOPSIS method into the Natural Resources Asset Accountability Audit of Officials evaluation system to help improve the objectivity and fairness of audit results.

By applying this evaluation system to Jiangxi Province, one of the national ecological civilization experimental areas, it has revealed that the natural resource asset situation of Jiangxi Province has been continuously improving during the period 2015-2019. After conducting a specific analysis of the three major subsystems, it is found that the environmental subsystem drives the improvement of the overall score. The continuous improvement of atmospheric conditions in the environmental subsystem has become the core driving factor. The main shortcoming of Jiangxi Province is that the resource subsystem and economic subsystem have not yet reached a stable state. In the future economic development of Jiangxi Province, it should stick to the resource-saving economic route and focus on the efficiency of the use of natural resource assets and pay attention to the increase in GDP while at the same time. Improve the efficiency of resource use to achieve a high-quality development pattern.

Other provinces can also use similar ideas to evaluate the natural resources and resource conditions of the province and reveal the driving factors and shortcomings of the coordinated development of economy and environment by constructing the three major subsystems of energy, economy, and environment and adjusting the focus of work in a targeted way to quickly make up for shortcomings and promote the formation of a coordinated economic and environmental development. In addition, local leading officials can take into account local natural resource endowments in accordance with local conditions and formulate an evaluation system with local characteristics.

\subsection{Recommendations}

\subsubsection{Use Modern Technology to Improve the Natural Resource Database}

In the process of applying the evaluation system of this article to Jiangxi Province, some natural resource assets in Jiangxi Province have problems such as incomplete registration and lagging access to resources. The resource management cycles have a strong lag relative to the term of office, such as mineral resources. The statistics of Jiangxi's coal reserves, iron ore reserves, copper reserves and other data have only been updated to 2016. The imperfection of statistical data will lead to the lack of some quantitative indicators and undermine the comprehensiveness of the evaluation system.

\subsubsection{Develop a System of Audit Indicators with Local Condition}

The application of the evaluation of the provincial-level Natural Resources Asset Accountability Audit of Officials evaluation system can also provide some suggestions for other provinces, and provide authentic reference for the provincial leaders, as well as, better adapt to the needs of local governments at all levels. In respect to practice, it is recommended that relevant professionals can make appropriate additions, deletions, deletions and modifications to the evaluation indicators based on local geographic characteristics.

5.2.3. Make the Correlation between the Balance Sheet of Natural Resources and the Audit Evaluation System

With the comprehensive implementation of the natural resource balance sheet policy in many provinces across the country, the era of normalization of Natural Resources Asset Accountability Audit of Officials is coming. It is believed that in the future, many provinces will release balance sheets covering water resources, land resources, and forest resources, and each province can audit the management of natural resources assets of leading cadres based on the new perspective of natural resources balance sheets. 
5.2.4. Fully Implement the Accountability System for Ecological Environment and Strive for "Look Back" of Natural Resource Asset Audit

Natural resource asset auditing is not the end of natural resource protection. Through the establishment of a sound ecological and environmental accountability system, local leading officials are responsible for the ecological effects during their term of office, so as to encourage the next leading officials to fulfill their ecological governance obligations and strive for a sustainable development.

Author Contributions: Conceptualization, H.X.; methodology, H.X. and Y.L.; data curation, Y.L. and J.H.; writing, H.X., Y.L. and J.H.; supervision, H.X. All authors have read and agreed to the published version of the manuscript.

Funding: This research was funded by The National Social Science Fund of China (grant numbers: 21CJL022), 2020 Jiangxi Province Educational Science Planning Project: Research on the Path of Incorporating Xi Jinping's Ecological Civilization Thought into College Students' Ecological Moral Education(grant numbers: 20YB004), Jiangxi Province Higher Education Reform Research Provincial Project: "Trinity" Model: Research and Practice of Xi Jinping's Thought of Ecological Civilization into the Course of "Ecological Economics" (grant numbers: JXJG-20-1-35).

Institutional Review Board Statement: Not applicable.

Informed Consent Statement: Not applicable.

Data Availability Statement: The data in this article are from China National Bureau of Statistics and the Jiangxi Provincial Statistical Yearbook and are available on request from the corresponding author.

Conflicts of Interest: The authors declare no conflict of interest.

\section{Appendix A}

Table A1. Natural resources asset accountability audit of officials' evaluation indicators.

Main Indicators $\quad$ Sub-Indicators

Total water resources $C_{11}$ Amount of water resources per capita $C_{12}$

Amount of surface water resources $C_{13}$

Amount of underground water $\mathrm{C}_{14}$

Forest area $\mathrm{C}_{15}$

Forest stock $\mathrm{C}_{16}$

Total standing wood accumulation $\mathrm{C}_{17}$

Arable land area $\mathrm{C}_{18}$

Urban construction land area $\mathrm{C}_{19}$

Energy subsystem $\mathrm{C}_{1}$

Area of urban landscaped areas $C_{110}$

Forestry land area $\mathrm{C}_{111}$

Total Mineral Resources Storage $C_{112}$

Coal reserves $C_{113}$

Iron Ore Reserves $\mathrm{C}_{114}$

Vanadium Ore Reserves $C_{115}$

Copper Ore Reserves $C_{116}$

Lead Ore Reserves $C_{117}$

Zinc Ore Reserves $C_{118}$

Sulfur iron ore reserves $C_{119}$

Phosphate Ore Reserves $C_{120}$

Kaolin Reserves $C_{121}$

Retention of rare mineral species $C_{122}$ 
Table A1. Cont.

\section{Main Indicators}

Economic Subsystem $C_{2}$

\section{Sub-Indicators}

Water Consumption of 10,000 GDP $C_{21}$ Water supply $\mathrm{C}_{22}$

Hydroelectric power generation $\mathrm{C}_{23}$

Effective utilization coefficient of water $C_{24}$ Total forestry output value $C_{25}$

Land for construction of 10,000 GDP $C_{26}$ Mining output value $\mathrm{C}_{27}$

Growth rate of mining output value $C_{28}$ Mineral ratio of 10,000 Yuan GDP $C_{29}$

Total city gas supply $\mathrm{C}_{210}$

Production of raw coal $\mathrm{C}_{211}$ Coke Production Volume $\mathrm{C}_{212}$

Sewage Discharge Volume $C_{31}$

Total Wastewater Treatment $C_{32}$

Treatment capacity of wastewater facilities $C_{33}$

Industrial wastewater emissions $C_{34}$

Forest coverage rate $C_{35}$

Forest pest control rate $\mathrm{C}_{36}$

Urban greening coverage area $C_{37}$

Soil erosion control area $C_{38}$

Area of Nature Reserve $C_{39}$

Environmental Subsystem $\mathrm{C}_{3}$
Utilization Rate of Mineral Resources Reserves $C_{310}$

Mineral resources recovery rate $C_{311}$

Land reclamation rate of mining areas $\mathrm{C}_{312}$

Total industrial waste gas emissions $\mathrm{C}_{313}$

Treatment capacity of exhaust gas facilities $C_{314}$

Industrial sulfur dioxide emissions $\mathrm{C}_{315}$

Industrial nitrogen oxide emissions $C_{316}$

Industrial smoke (dust) emissions $\mathrm{C}_{317}$ $\mathrm{PM}_{2.5}$ concentration $\mathrm{C}_{318}$

\section{References}

1. The World Bank, GDP (Current US\$). Available online: https:/ / data.worldbank.org/indicator/NY.GDP.MKTP.CD?view=chart (accessed on 16 December 2021).

2. The World Bank, GDP Growth (Annual \%). Available online: http://worldbank.org/ (accessed on 20 December 2021).

3. Distribution of Fossil Fuel $\mathrm{CO}_{2}$ Emissions Worldwide in 2020, by Select Country. Available online: https://www.statista.com/ statistics /271748/the-largest-emitters-of-co2-in-the-world/ (accessed on 5 November 2021).

4. Guo, M.; Hu, Y.; Yu, J. The role of financial development in the process of climate change: Evidence from different panel models in China. Atmos. Pollut. Res. 2019, 10, 1375-1382. [CrossRef]

5. Wackernagel, M.; Onisto, L.; Bello, P.; Linares, A.C.; Falfán, I.S.L.; García, J.M.; Guerrero, A.I.S.; Guerrero, M.G.S. National natural capital accounting with the ecological footprint concept. Ecol. Econ. 1999, 29, 375-390. [CrossRef]

6. Wachernagel, M.; Rees, W.E. Our Ecological Footprint: Reducing Human Impact on the Earth; New Society Publishers: Gabriola Island, BC, Canada, 1996.

7. Ahmed, Z.; Asghar, M.M.; Malik, M.N.; Nawaz, K. Moving towards a sustainable environment: The dynamic linkage between natural resources, human capital, urbanization, economic growth, and ecological footprint in China. Resour. Policy 2020, 67, 101677. [CrossRef]

8. Ahmed, Z.; Wang, Z.; Mahmood, F.; Hafeez, M.; Ali, N. Does globalization increase the ecological footprint? Empirical evidence from Malaysia. Environ. Sci. Pollut. Res. 2019, 26, 18565-18582. [CrossRef]

9. Charfeddine, L. The impact of energy consumption and economic development on Ecological Footprint and $\mathrm{CO}_{2}$ emissions: Evidence from a Markov Switching Equilibrium Correction Model. Energy Econ. 2017, 65, 355-374. [CrossRef]

10. Destek, M.A.; Ulucak, R.; Dogan, E. Analyzing the environmental Kuznets curve for the EU countries: The role of ecological footprint. Environ. Sci. Pollut. Res. Int. 2018, 25, 29387-29396. [CrossRef] [PubMed]

11. Galli, A.; Kitzes, J.; Niccolucci, V.; Wackernagel, M.; Wada, Y.; Marchettini, N. Assessing the global environmental consequences of economic growth through the Ecological Footprint: A focus on China and India. Ecol. Indic. 2012, 17, 99-107. [CrossRef]

12. Wu, F.; Yang, X.; Shen, Z.; Bian, D.; Babuna, P. Exploring sustainability and decoupling effects of natural capital utilization in China: Evidence from a provincial three-dimensional ecological footprint. J. Clean. Prod. 2021, 295, 126486. [CrossRef] 
13. Lin, D.; Hanscom, L.; Murthy, A.; Galli, A.; Evans, M.; Neill, E.; Mancini, M.S.; Martindill, J.; Medouar, F.-Z.; Huang, S.; et al. Ecological Footprint Accounting for Countries: Updates and Results of the National Footprint Accounts, 2012-2018. J. Resour. 2018, 7, 58. [CrossRef]

14. Gu, B.J.; Zhang, X.L.; Bai, X.M.; Fu, B.J.; Chen, D.L. Four steps to food security for swelling cities. Nature 2019, 566, 31-33. [CrossRef]

15. Global Footprint Network. National Footprint Accounts. 2021. Available online: https://data.footprintnetwork.org/\#/ countryTrends? $\mathrm{cn}=351$ \&type $=$ BCpc,EFCpc (accessed on 2 February 2021).

16. Zhen, L.; Du, B. Ecological Footprint Analysis Based on Changing Food Consumption in a Poorly Developed Area of China. Sustainability 2017, 9, 1323. [CrossRef]

17. Costanza, R.; Daly, L.; Fioramonti, L.; Giovannini, E.; Kubiszewski, I.; Mortensen, L.F.; Pickett, K.E.; Ragnarsdottir, K.V.; De Vogli, R.; Wilkinson, R. Modelling and measuring sustainable wellbeing in connection with the UN Sustainable Development Goals. Ecol. Econ. 2016, 130, 350-355. [CrossRef]

18. The General Office of the Central Committee of the Communist Party of China and the General Office of the State Council issued the "Regulations on the Natural Resources Asset Accountability Audit of Officials (for Trial Implementation)". Available online: http:/ / www.gov.cn/zhengce/2017-11/28/content_5242955.htm (accessed on 8 October 2021).

19. Cheng, S.K.; Shen, L.; Feng, Z.M.; Zhong, S. The development history and prospect of natural resources research in China. J. Natl. Resour. 2020, 33, 1675-1685.

20. Shen, L.; Zhong, S.; He, L.; Tao, J.G. Research on Accounting and Balance Sheet of Natural Resources with Double-Entry Bookkeeping. J. Natl. Resour. 2018, 33, 1675-1685.

21. Qibo, J.; Qingmei, T. National environmental audit and improvement of regional energy efficiency from the perspective of institution and development differences. J. Energy 2020, prepublish. [CrossRef]

22. Sun, W.Y.; Sun, Y.Y. An Empirical Study on the Impact of Resource-Environment Audit on High-Quality Economic Development: A Pilot Study on the Audit of Natural Resources Assets of Leading Cadres as an Example. Ecol. Econ. 2020, 36, 166-171.

23. Zhang, Q.; Tan, Z. Environmental Governance Effect of Natural Resources and Assets Accountability Audit of Officials During Period of Tenure. Audit. Res. 2019, 1, 16-23.

24. Sun, Y.F.; Liu, X.N. Natural Resources and Assets Accountability Audit of Officials during Period of Tenure and Fulfillment of Corporate Environmental Responsibility. Audit. Res. 2021, 5, 42-53.

25. Quan, J.; Liu, W.J.; Xie, B.S. Leading Officials' Accountability Audit of Natural Resources Political Connection and the Cost of Equity Capital. Audit. Res. 2018, 2, 46-54.

26. Cao, Y.S.; Ma, R.H. Natural Resources and Assets Accountability Audit of Officials and Green M\&A-Evidence from Chinese Heavily Polluting Listed Companies. J. Guizhou Univ. 2021, 5, 81-91.

27. Jiang, Q.J.; Shun, F.C. Leading Officials' Natural Resources Accountability Audit and Corporate Tax Avoidance-A Study based on natural experiment of goverment leaders' promotion system. Audit. Res. 2019, 3, 35-43.

28. Åkerman, M.; Peltola, T. How does natural resource accounting become powerful in policymaking? A case study of changing calculative frames in local energy policy in Finland. Ecol. Econ. 2012, 80, 63-69. [CrossRef]

29. Wackernagel, M.; Rees, W.E. Perceptual and structural barriers to investing in natural capital: Economics from an ecological footprint perspective. Ecol. Econ. 1997, 20, 3-24. [CrossRef]

30. El Serafy, S. Green accounting and economic policy. Macroecon. Environ. 2013, 21, 251-278. [CrossRef]

31. World Bank. Expanding the measure of wealth: Indicators of environmentally sustainable development; The Environment Department, The World Bank: New York, NY, USA, 1997.

32. United Nations; European Commission; International Monetary Fund; Organization for Economic Cooperation and Development World Bank. Handbook of National Accounting_-Integrated Environmental and Economic Accounting 1993 (SEEA 1993), Final ed.; The Statistical Commission of the United Nations: New York, NY, USA, 1993.

33. United Nations; European Commission; International Monetary Fund; Organization for Economic Cooperation and Development; World Bank. Handbook of National Accounting_-Integrated Environmental and Economic Accounting 2003 (SEEA 2003), Final ed.; The Statistical Commission of the United Nations: New York, NY, USA, 2003.

34. United Nations; European Union; Food and Agriculture Organization of the United Nations; International Monetary Fund; Organization for Economic Cooperation and Development; The World Bank. System of Environmental-Economic Accounting 2012-Central Framework (SEEA Central Framework), Final ed.; United Nations: New York, NY, USA, 2012.

35. Castelo, B.M. Sustainability Reporting Guidelines. In Encyclopedia of Corporate Social Responsibility; Idowu, S.O., Capaldi, N., Zu, L., Gupta, A.D., Eds.; Springer: Berlin/Heidelberg, Germany, 2013; pp. 2389-2395.

36. Yale University Center for Environmental Law and Policy; Columbia University Center for International Earth Science Information Network. 2005 Environmental Sustainability Index: Benchmarking National Environmental Stewardship; World Economic Forum Annual Meeting 2005: Davos, Switzerland, 2005. Available online: https://sedac.ciesin.columbia.edu/es/esi/ESI2005_ policysummary.pdf (accessed on 10 October 2021).

37. OECD Environmental Performance Reviews: Canada. 2017. Available online: https://www.oecd.org/canada/oecdenvironmental-performance-reviews-canada-2017-9789264279612-en.htm (accessed on 19 December 2017).

38. Xu, H.; Qu, J. Research on the Target, the Content, and the Evaluation System of Natural Resources Performance Audit. Audit. Res. 2012, 2, 14-19+51.

39. Liu, B.C. Based on natural resource assets responsibility audit evaluation index System Research. Financ. Superv. 2016, 8, 98-100 
40. Lin, Z.H. An Exploration on Accountability Audit of Natural Resource. Audit. Res. 2014, 5, 10-14.

41. Chen, C.B.; Geng, X.Y.; Meng, C. Thinking Based on the Practice of Accountability Audit of Natural Resource in Jiaozhou City. Audit. Res. 2016, 4, 10-14.

42. Pan, W.M.; Ding, M.L. Practical Modeling for Natural Resources and Assets Accountability Audit of Leaders and Officials During Period of Tenure-A pilot audit in Shaoxing City. Audit. Res. 2018, 3, 53-62.

43. Ma, P.; Xie, J.; Guo, S.J.; Guo, L.Q.; Zhou, Q.F. Construction of the Index System for the Analysis of Doubtful Points in the Audit of Natural Resources Assets-Taking Yunnan Province as an Example. Commun. Fin. Account. 2021, 19, 114-119.

44. Huang, R.B. The construction of the evaluation index system of leading cadres' natural resources assets out of office audit-Based on the perspective of main functional area. Huxiang Forum 2020, 33, 79-90.

45. Feng, Y.; Feng, J.K.; Liu, P.W. Recognition of Outgoing Audit Responsibility of Leading Cadres' Natural Resource Assets Based on Ecological Carrying Capacity. Fin. Account. Mon. 2021, 9, 113-117.

46. Geng, J.X.; Lv, X.M.; Liu, S.R. Research on the Outgoing Audit of Resource Assets Based on the Carrying Capacity of Resources and Environment: Taking my country's Forest Resources as an Example. Friends Account. 2019, 24, $104-112$.

47. Guo, S.J.; Fan, F.J.; Zhao, J.J.; Ma, P. Research on Resource and Environmental Carrying Capacity in Natural Resource Asset Auditing: Taking Pu'er City, Yunnan Province as an Example. Ecol. Econ. 2021, 37, 172-178.

48. Qin, X.L.; Liu, J.M.; Wang, J.Z. Research on the Outgoing Audit of Natural Resource Assets of Leading Cadres-Based on the Practice of Jiangsu Province. Friends Account. 2017, 20, 97-101.

49. Li, S.Y.; Xie, H.; Lu, L.N. Construction and Application of Natural Resource Asset Audit Evaluation Index System-Based on Fuzzy Analytic Hierarchy Process. Friends Account. 2018, 10, 27-30.

50. Zhang, L.D.; Xie, C.X. Research on the Extraction and Analysis of Doubtful Points in the Audit of Natural Resources Assets Leaving Office of Leading Cadres Based on Deep Convolution Neural Network. Stat. Infor. Forum. 2021, 36, 75-83.

51. Guo, X. A Summary of the Research on the Outgoing Audit of Natural Resources Assets of Leading Cadres. Audit. Res. 2017, 2, 25-30.

52. Li, L.S.; Yang, H.C.; Liu, J. Evaluation Study on Comprehensive Developing Ability of Regional Manufacturing Industry in China Based on the Empirical Analysis of Manufacturing Industry in East, Middle and West China. China Soft Sci. 2014, 2, 121-129. [CrossRef]

53. A Probe into the Concept of Outgoing Auditing of Natural Resources Assets of Leading Cadres in my Country. Available online: http:/ / www.audit.gov.cn/n6/n41/c78215/content.html (accessed on 10 October 2021).

54. He, L.; Shen, L.; Tao, J.G.; Zhong, S.; Zhang, Y. Research on Equilibrium Relation of Natural Resources Balance Sheet Based on Double-Entry Bookkeeping. J. Natl. Resour. 2018, 33, 1697-1705.

55. China Launches a Pilot Program for Auditing the Departure of Leading Cadres' Natural Resource Assets. Available online: http:/ / www.gov.cn/xinwen/2015-11/10/content_5006663.htm (accessed on 20 October 2021).

56. Jiangxi Statistical Yearbook. 2020. Available online: http://tjj.jiangxi.gov.cn/resource/nj/2020CD/indexch.htm (accessed on 4 January 2021). 